\title{
Reflections on The Book of Mormon musical: Flirtations with Mormon theology
}

"The Book of Mormon' is like looking into a fun-house mirror; the reflection is hilarious but not really you. The nose is yours but swollen out of proportion"

Professor of Mormon Studies, Richard Bushman (cited in Kernis, 2011, n.p.).

\section{Introduction}

Since childhood, I have been fascinated by religion. This fascination - and frequent obsession - has remained a significant part of my psyche. I was raised within a syncretistic Māori theological context: a mixture of ancient Māori spirituality blended seamlessly with various Christian denominations and Ringatū - a syncretistic faith founded by the nineteenth century Māori prophet, Te Kooti Arikirangi Te Turuki. I attended all sorts of churches. I genuflected with deep sincerity and drama when entering a Catholic church. I spoke in tongues at a Christian camp where we prayed for the fall of Saddam Hussein. In 1996, when I was 16, I converted to Mormonism and became a member of The Church of Jesus Christ of Latter-Day Saints - more commonly known as the Mormon Church. 
I had been seduced by a sense of absolute belonging coupled with fun activities and the potential of one day serving a mission and emulating the actions of the American missionaries that taught me about the Mormon Church. In 1997 I attended the Church College of New Zealand for my final year of high school. Church College was an unforgettable experience punctuated with life-long - or as Mormons might say, "eternal" friendships, and many more fun activities! In 2002 I was called by the Mormon Church to serve a two year mission. I had doors slammed in my face. I was accused of worshipping the devil. I was asked to show my "Mormon underwear". ${ }^{1}$ I was verbally abused, threatened with violence, and chased by vicious dogs. I rode bicycles and walked the streets, come rain, hail or storm, door knocking and preaching the Mormon gospel: the good news that an American prophet named Joseph Smith had restored the true gospel to the earth! In 2003 I was removed from the mission and excommunicated from the Church by the Mission President for a serious breach of Church rules. Following excommunication, I reverted back to the syncretic theology of my upbringing, using Māori Anglicanism as my waka of faith.

The Book of Mormon was written by South Park co-creators, Trey Parker and Matt Stone, and Avenue Q's, Robert Lopez, and premiered in 2011; the musical won nine Tony Awards in 2011 and has maintained its popular success with a continued presence on Broadway (Hoxworth, 2017). The Book of Mormon toured nationally twice in the US and debuted in the West End in 2013. In 2017 the showed opened in Melbourne and was then moved in Sydney in 2018. In 2012 I had intended to see The Book of Mormon while in New York, but the opportunity slipped away. In May 2018 I had the chance to enjoy The Book of Mormon in Sydney at the Lyric Theatre. This article will explore my thoughts with regard to the musical in light of my own, albeit

1 Devout Mormons wear what they call the Temple Garment; they receive this after making covenants with God in the Temple. These sacred undergarments may be likened to the holy vestments of a priest: an outward sign of an inward commitment. 
rather brief, Mormon experiences: my flirtations with Mormon theology. ${ }^{2}$

\section{Prologue: The Hill Cumorah}

There was something familiar about the Hill Cumorah prologue at the beginning of The Book of Mormon. It reminded me of the Temple Pageant - music composed by Robert Manookin (Graham, 2007) - that I saw at the Hamilton New Zealand Temple in the late 80s or early 90s with a bus-load of Mormons and non-Mormons (I was non-Mormon at that stage) from Murupara, my hometown. The show was impressive. It was colourful. The music was sublime. One of the most significant parts of the show was when Jesus - Mormons more often than not refer to Jesus as "The Saviour" - appears on the roof of the Hamilton New Zealand Temple clothed in white, glowing like a beacon atop the most significant building in New Zealand Mormonism.

I sat next to young woman who had seen the show in New York. Her hopes were that the Sydney version would be as good as the one on Broadway. We both sat in anticipation, admiring the proscenium, which to me reflected some of the features of the San Diego California Temple, complete with a golden replica

2 A thorough explanation of the Book of Mormon, Mormon theology, and the history of Mormonism in Aotearoa New Zealand is beyond the scope of this paper. However, Robert Josephs (2012) work is very helpful with regard to exploring Māori responses to Mormonism and is a good place to start. There are also a range of US-based Mormon journals on Mormon theological thought, including: Dialogue: A Journal of Mormon Thought; Element: A Journal of Mormon Philosophy and Theology; International Mormon Studies; Interpreter: A Journal of Mormon Scripture; Journal of Book of Mormon Studies; John Whitmer Historical Association Journal; Journal of Mormon History; Mormon Historical Studies; Mormon Studies Review; Restoration Studies; Sunstone. For more information on the basic beliefs of the Mormon Church please see: https://www.mormon.org/ 
of the Angel Moroni blowing on this trumpet - the ultimate Mormon icon. According to set designer, Scott Pask:

The Proscenium, which is inspired by contemporary Mormon temples and other religious architecture, is filled with illuminated stained glass windows that transform in color throughout the evening, and is topped by the gilded (and rotating!) statue of the Angel Moroni. This frames our entire evening, attributing an important pageant-like quality to the story. The Show Scrim and the architectural panels installed above each of the audience boxes are inspired by galactic views of the universe, combined with an inspirational greeting-cardstyle sunrise to create an imagined vision of Mormon heaven (cited in Hetrick \& Blank, 2011, n.p).

The prologue to The Book of Mormon begins as "[t]he Mormon theme blares out of trumpets. Upstage there is a large picture frame, depicting a biblical scene from the Book of Mormon" (Trey, Lopez, Stone, 2011, p. 1). According to Gerald S. Argetsinger (2016):

When I entered the Eugene O'Neil Theatre on March 23, 2011, to review the final preview of The Book of Mormon, I immediately recognized the small figure of the angel Moroni standing atop the proscenium arch, a clear reference to the architecture and iconography of LDS temple. When the curtain rose, I was probably the only person in the audience who recognized the "Mormon and Moroni" scene from the Hill Cumorah Pageant - a scene I had personally directed two decades prior. The Broadway 
actors were dressed in costumes echoing those designed and constructed by my wife, Gail Argetsinger, costume designer for the Mormon pageant (1978-1997). The thrill of recognition was repeated when I heard Andrew Rannells in his role as Elder Price sing "I am a Mormon; and a Mormon just believes." The five notes that repeat in the phrase "I am a Mormon" are the five notes, composed by Crawford Gates, that begin the opening "Trumpet Fanfare" for the Hill Cumorah Pageant (p. 17).

The prologue features Mormon who opines: "I am Mormon. My people sailed here from Israel to create a new civilization. These golden plates tell of our people and how we met...with Jesus Christ" (Parker, et al., 2011, p. 1). Jesus then appears to Mormon and declares: "I am Jesus. Take care of your golden plates, Mormon, for soon, your entire civilization will be gone and nobody will remember you" (Parker, et al., 2011, p. 1). To safeguard the plates, Mormon gives them to his son, Moroni who pronounces: "I am Moroni, the last of my kind. I shall BURY the golden plates, father, and perhaps one day, someone very special will find them..." (Parker, et al., 2011, p. 1). Setting up for the scene to follow, the Narrator says: "And lo, Moroni buried the golden plates high on a hill. Centuries later, the golden plates were found, giving birth to the fastest growing religion today! A church that even now sends missionaries out... All over the world..." (Parker, et al., 2011, p. 1).

\section{Missionary Training Center}

ELDER KEVIN PRICE, a young, dashing Mormon missionary in a white shirt and black tie, walks up with a big smile on his face, 
holding the Book of Mormon. He pantomimes ringing a doorbell, and we hear DING DONG! (Parker et al., 2011, p. 1).

When I entered the Missionary Training Centre or MTC in 2002, at that time located in Hamilton, Aotearoa New Zealand, it was a time of spiritual discovery. We were filled with zeal, ready to get out there and preach the gospel to all who would listen. The purpose of the MTC was to provide the required training to do the job. The main focus of our training was how to teach what was known to us as "the discussions". White (2010) argues: "The questions of what to teach and how to teach it have led to four sets of formal missionary discussions published by the Church beginning in 1952 and continuing on to 1961,1973 and 1986 " (p. v). ${ }^{3}$ The discussions that we were trained to use were a set of six lessons, contained in the Uniform system for teaching the gospel (1986), that covered the most fundamental tenets of the Church. These lessons were:

$\begin{aligned} \text { 1) } & \text { The plan of Our Heavenly Father } \\ \text { 2) } & \text { The Gospel of Jesus Christ } \\ \text { 3) } & \text { The Restoration } \\ \text { 5) } & \text { Eternal Progression } \\ \text { 6) } & \text { Membership in the Kingdom (White, } \\ \text { 2010, p. 6). } & \end{aligned}$

Part of the training - which was ongoing beyond the MTC was to commit to memory the bulk of the information in the discussions which spanned 117 pages. White (2010) asserts that the missionaries that trained with this version of the discussions were "...instructed to "master" the information in

$3 \quad$ White's (2010) work focusses on the Preach My Gospel missionary manual which was introduced in 2004, two years after my training in the MTC, and contains the fifth set of missionary discussions published by the Church. 
the left hand column because it presents the doctrines of the gospel" (p. 6). We were also taught a strategy called "the commitment pattern" - a technique used to engender commitment from a potential convert. White (2010) argues that the addition of the commitment pattern was the most significant change in the 1986 set of discussions as compared with the previous version. In the Instructions for the Discussions section of the missionary lessons it states:

These discussions are based on a simple pattern for helping investigators make and keep the basic commitments. First, you prepare the investigators to feel and recognize the Spirit. When they feel the Spirit, invite them to make a specific commitment. Each discussion should lead to one or two commitment invitations. After the investigators have made a commitment, do all you can to help them keep it (The Church of Jesus Christ of Latter-Day Saints, 1986, p. 1).

According to White (2010):

This process of preparing, inviting and following up with an investigator's commitments was woven throughout the 1986 missionary discussions. Additional commitment pattern skills included these four items: building relationships of trust with the investigator, presenting the message, asking open ended questions to find out an investigator's level of understanding and receptiveness to the message, and resolving concerns (p. 6). 


\title{
Hello!
}

\author{
ELDER PRICE \\ HELLO, \\ MY NAME IS ELDER PRICE, \\ AND I WOULD LIKE TO SHARE \\ WITH YOU \\ THE MOST AMAZING BOOK \\ (Parker, et al., 2011, p. 1)
}

Our training was intended to prepare us - missionaries from all over the world - for the "uniform teaching of the gospel" to the people of Aotearoa New Zealand. Following training we were sent our separate ways to various locations. We were naïve but we were as prepared as we could be. Knocking on doors was both a frightening and exciting experience. In Aotearoa New Zealand, very few homes have door bells (at least in the locations within which I served). The opening number of The Book of Mormon, Hello! which features lots of door bell ringing connected with my missionary experiences despite the lack of door bells. When doors opened we stood there with smiles on our faces, excited to be messengers for God, and would say: "Hello. We are from the Church of Jesus Christ of Latter-Day Saints and we'd love to share a message with you about eternal life" or something similar. The lyrics in the song Hello! capture the essence of our message, although the song lyrics are exaggerated and purposefully cheesy. We were on their doorsteps because we believed, idealistically perhaps, that the message of the Book of Mormon and the Church would change their lives. That if they just had faith in the Church everything would work out and that, as promised in Malachi 3:10, the windows of heaven would be opened.

Referring to the theology of Reinhold Niebuhr and the notion of religious foolishness, Sirvent and Baker (2016) argue: 
The foolishness Niebuhr speaks of manifests itself in two principal forms: (1) an unrealistic view of the world and (2) the conviction that one's group possesses unfettered, unmediated, and unconditioned access to the divine and is therefore insusceptible to the pride and self-love that plague other religious groups (p. 44).

Looking back on my missionary experiences, I think that I experienced religious foolishness. I had an unrealistic view of the world and at that time believed that adherence to Church doctrine and religious conformity would solve the problems of those who heard and accepted the Mormon gospel. Life teaches us that things are not quite as simple as that. The Church of Jesus Christ of Latter-Day Saints and her membership maintain that their religion is the one true church, the one true faith, and that through her tenets, doctrines and sacraments (Mormons call these, ordinances) a person and their entire family have the potential to be exalted to Godhood. This unshifting belief fulfils the second of Niebuhr's parameters for religious foolishness. Though it is not just the Mormons who experience religious foolishness:

...the foolishness of the type of religious belief depicted in The Book of Mormon runs far deeper than the peculiar beliefs of a particular religion. Rather, what disturbs us most about the version of faith expressed by the missionaries is its fundamentally naïve and selfserving approach to life's most profound questions. The object of Parker and Stone's satire is therefore something far more pervasive than the Mormon Church itself - indeed, their criticisms ultimately seem to be directed not at 
people of a particular faith but of a particular mindset (Sirvent \& Baker, 2016, p. 43).

As a missionary I believed a lot in the truth of the Mormon Church. However, in hindsight, I also realise that my faith was and always has been underpinned by syncretistic theology. It was how I was raised. It is part of my whakapapa. It is how our whānau express faith. It is part of the legacy left to us by the prophet Te Kooti embedded within the Ringatū faith which is so prominent in my Patuheuheu whakapapa. The mixing together of faith traditions comes naturally to us/me. My realisation that the world's problems are complex and cannot be solved by any one book or religion, and that there is no one true faith that has all the answers, releases me from the shackles of religious foolishness. But, of course, I am far from free! 
Image 1: Elder Rangiwai (me!) outside Christchurch Cathedral, 2002

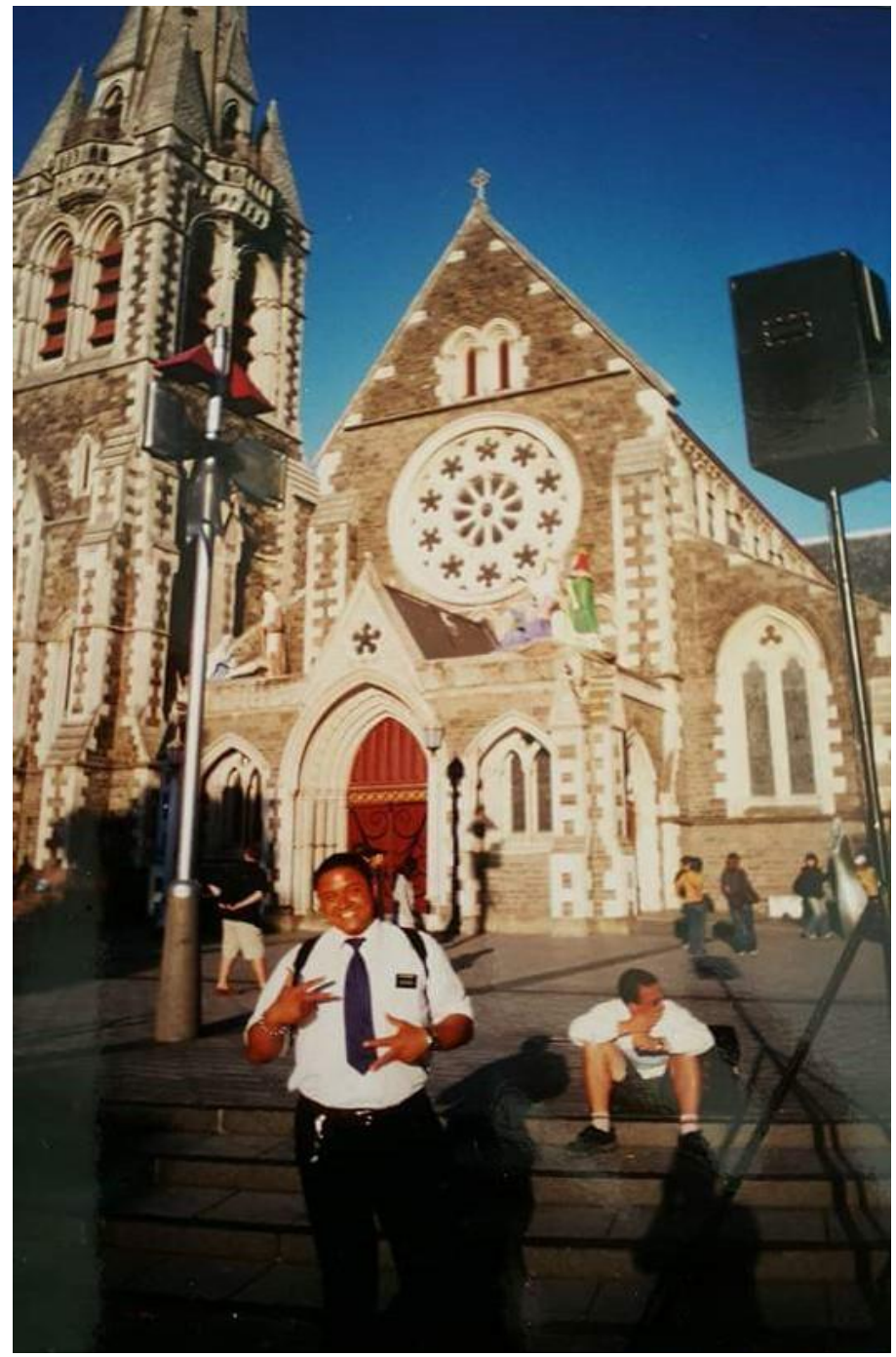

(B. Rangiwai, personal collection) 


\title{
Two by two
}

Mormon missionaries travel and preach in pairs. According to the Missionary Handbook: "Preaching the gospel two by two is the pattern established by the Lord. The testimonies of two companions support each other in proclaiming the truth and bearing witness of it" (The Church of Jesus Christ of Latter-Day Saints, 2006, p. 29). ${ }^{4}$ Companionships are a critical part of the Mormon proselyting strategy: "Companions support each other in other phases of their work. They help each other learn and grow. They strengthen each other in times of difficulty. They can provide protection from physical danger, false charges, and temptation" (The Church of Jesus Christ of Latter-Day Saints, 2006, p. 30). In the musical, the importance of the companionship relationship is emphasised but it is exaggerated in the bedroom scenes where Elders Price and Cunningham are seen sleeping in the same bed. The Missionary Handbook is clear that one must "...always sleep in the same room as your companion, but not in the same bed" (The Church of Jesus Christ of Latter-Day Saints, 2006, p. 31).

\author{
ELDER GRANT \& ELDER YOUNG \\ TWO BY TWO WE'RE MARCHING \\ DOOR TO DOOR! \\ 'CAUSE GOD LOVES MORMONS \\ AND HE WANTS SOME MORE! \\ A TWO-YEAR MISSION IS OUR \\ SACRIFICE \\ WE ARE THE ARMY OF THE \\ CHURCH OF JESUS CHRIST! \\ [OF LATTER-DAY SAINTS] \\ (Parker, et al. 2001, p. 8).
}

$4 \quad$ I served my mission from 2002 and so this 2006 version of the Missionary Handbook contains some differences in it. However, with the regard to the content above, the message is the exactly the same. I was unable to source an older copy of the Missionary Handbook but found this 2006 edition online in PDF format. 
In the song Two by two, Elders Price and Cunningham are assigned to be permanent companions and are to be sent to Uganda $^{5}$ to find new converts. Mormon missionaries are not actually assigned to permanent companionships; rather, they are assigned a new companion after a certain period of time in my experience it was generally every six to 12 weeks or so and may have many companions during the course of a mission. However, for The Book of Mormon plot to work, Price and Cunningham needed to be permanently assigned to one another as the story is based around these two characters and their interactions with each other, the other missionaries, and the local Ugandans. In my experience, the mission was a

5 In Uganda, Elders Price and Cunningham are confronted with a strange and alien environment. The problem with The Book of Mormon's Uganda is that is bears no resemblance to Uganda or to Africa but is instead a collection of distorted views and stereotypes about the African "other". Cima (2016) opines:

The Book of Mormon's Uganda encapsulates Western stereotypes about Africans. While the barbs lobbed at the missionaries are laser-targeted and good-natured, those hurled at the villagers are carpet bombs not aimed specifically at Uganda, nor at anything recognizably African, but at a country of the Western imagination called "Africa" (pp. 130-131).

With regard to the portrayal of the Ugandans, Farmer (2011) argues that The Book of Mormon "...gives Africans far more offense than Mormons" (n.p.). The Ugandans are represented as foolish buffoons in desperate need of saving by the "west' and in particular by an American, Mormon gospel of salvation. According to Cima (2016): Parker, Lopez, and Stone's Mormons do have all the answers. In the end, they save the Africans by threatening the general with American, and implicitly white, violence. The final scene presents the converted African villagers wearing the signature white shirts and black ties of the missionaries, ready to spread the gospel ( $\mathrm{p}$. 138).

Parker and Stone describe the "Africa" of The Book of Mormon in this way:

We just wanted it to be that place that you always read about where - and a lot of times it's sub-Saharan Africa, it seems like, I mean, lately, it's been Haiti - where it's just that place that you go to, "Can this place get a break? They have earthquakes and then cholera and then a warlord and then a famine and then no water?" It was just supposed to be that place (cited in Cima, 2016, p. 131). 
challenging time where my faith (or lack thereof) was tested; for it is faith, and probably social and religious pressure, that motivated me to walk the streets with my companion in search of people to teach. For Elder Price, his mission is his chance to prove himself.

\section{ELDER PRICE}

THE MOST IMPORTANT TIME OF

A MORMON KIDS LIFE

IS HIS MISSION.

A CHANCE TO GO OUT AND HELP

HEAL THE WORLD,

THAT'S MY MISSION.

SOON I'LL BE OFF IN A DIFFERENT

PLACE

HELPING THE WHOLE HUMAN

RACE

I KNOW MY MISSION WILL BE

SOMETHING INCREDIBLE

(Parker, et al., 2011, p. 8).

\section{Turn it off}

In the song Turn it off, the message is that as a Mormon, one must "turn off" sinful thoughts. Elder Price, having just arrived in Uganda, is feeling confused about his mission. The Elders break into song about how easy it is during harrowing times to just "turn it off!"

\section{ELDER MCKINLEY:}

...TURN 'EM OFF

LIKE A LIGHT SWITCH, JUST GO "CLICK"

IT'S A COOL LITTLE MORMON TRICK.

WE DO IT ALL THE TIME 
(Parker, et al., 2011, p. 25).

In the song Elder Church sings about his father abusing his mother and the suggestion too is that Elder Church is also being abused or threatened by his father.

\author{
ELDER CHURCH: \\ ...I'D SEE HER ALL SCARED AND MY \\ SOUL WAS DYIN!! \\ MY DAD WOULD SAY TO ME, \\ "NOW DON'T YOU DARE START \\ CRYIN!" \\ TURN IT OFF! \\ (Parker, et al., 2011, p. 26).
}

Elder Thomas sings about how his sister was diagnosed with cancer and how she asked for him on her death bed. However, Elder Thomas was lined-up outside the Apple store waiting to purchase the latest iPhone.

\title{
ELDER THOMAS:
}

...SHE LAID THERE DYING WITH

MY FATHER AND MOTHER.

HER VERY LAST WORDS WERE

'WHERE IS MY BROTHER?'

(Parker, et al., 2011, p. 26).

Elder McKinley's issue to overcome are his homosexual thoughts. He recalls a time when he was younger when he fantasised about his homosexual desires for his best friend.

\section{ELDER MCKINLEY:}

I THOUGHT ABOUT US ON A

DESERTED ISLAND 


\section{ELDERS:}

WE'RE ALL ALONE

\section{ELDER MCKINLEY:}

WE'D SWIM NAKED IN THE SEA

AND THE HE'D TRY AND -

WHOA! TURN IT OFF!

LIKE A LIGHT SWITCH.

THERE, IT'S GONE.

\section{ELDER CHURCH:}

Good for you!

\section{ELDER MCKINLEY:}

MY HETERO SIDE JUST WON.

I'M ALL BETTER NOW.

BOYS SHOULD BE GIRLS, THAT'S HEAVENLY FATHER'S

PLAN.

SO IF YOU EVER FEEL YOU'D RATHER BE WITH A MAN TURN IT OFF.

(Parker, et al., 2011, p. 27).

Elder Price assures that Elder McKinley that having homosexual thoughts is fine, as long as he does not act upon these thoughts. This line of thinking is completely consistent with current Mormon thinking around homosexuality. According to the Church:

The Church distinguishes between samesex attraction and homosexual behavior. People who experience same-sex attraction or identify as gay, lesbian, or bisexual can make and keep covenants with God and fully and worthily participate in the Church. Identifying as gay, 
lesbian, or bisexual or experiencing same-sex attraction is not a sin and does not prohibit one from participating in the Church, holding callings, or attending the temple.

Sexual purity is an essential part of God's plan for our happiness. Sexual relations are reserved for a man and woman who are married and promise complete loyalty to each other. Sexual relations between a man and woman who are not married, or between people of the same sex, violate one of our Father in Heaven's most important laws and get in the way of our eternal progress. People of any sexual orientation who violate the law of chastity can be reconciled with God through repentance. As followers of Christ, we resist immoral behavior and strive to become like Him (The Church of Jesus Christ of Latter-Day Saints, 2018b, n.p.).

Elder McKinley, an advocate for the "turn it off" strategy sings about how he uses it to deal with his homosexual thoughts.

\section{ELDER MCKINLEY:}

...BEING GAY IS BAD BUT LYING IS

WORSE.

SO JUST REALIZE YOU HAVE A

CURABLE CURSE -

AND TURN IT OFF

(Parker, et al., 2011, p. 30).

\section{ELDER MCKINLEY:}

...IMAGINE THAT YOUR BRAIN IS

MADE OF TINY BOXES

THEN FIND THE BOX THAT'S GAY 


\author{
AND CRUSH IT!! \\ (Parker, et al., 2011, p. 30).
}

As a former Mormon who is also gay, I found Turn it off, while a little distorted, to be more or less accurate in terms of Mormon cultural and theological understandings around sexuality. Humming a Church song or saying a silent prayer in a sense a form of "turning it off" - were commonly espoused strategies, uttered by Church leadership, used - however ineffectively, to re-focus one's thoughts away from temptation.

\title{
I believe
}

In I Believe (Parker, et al., 2016, pp. 68-71), Elder Price sings the lines: "You cannot just believe part-way/You have to believe in it all” (Parker, et al., 2016, p. 68). For Newhouse (2016) "[t]his moment represents both Price's heroism and the real punch line of The Book of Mormon as an extended joke: on the one hand, we are meant to celebrate Price finally living out the strict demands of his faith; on the other, those tenets (especially when listed as simplistically as they are in the song "I Believe") sound bizarre enough to merit honest laughter from the (mostly) nonMormon audience..." (p. 79). This notion of just believing regardless of how strange the beliefs may sound "...is the tricky rhetorical line that The Book of Mormon straddles from beginning to end, encouraging us to laugh at beliefs, practices, and attitudes that seem at best naïve and at worst absurd..." (Newhouse, 2016, p. 79).

In an interview Kernis (2011) asked Professor of Mormon Studies, Richard Bushman the following:

Prof. Bushman, the character of Elder Price, an American Mormon missionary in modernday Uganda, questions his faith, but regains it 
while performing the song, "I Believe." He sings, "I believe that God has a plan for all of us. / I believe that plan involves me getting my own planet." Is that lyric based in Mormon belief? (n.p.).

Bushman responds thusly:

I have been living in California and Utah for the past year while the musical "The Book of Mormon" has been packing the house on Broadway. I have not seen the show, but I have read endless reviews, listened to parts of the score, and talked with Mormon friends who have seen it. Based on what I have heard, and the lyrics of Elder Price's song, the musical gets a lot of laughs, but it is not meant to explain Mormon beliefs.

Mormons experience the show like looking at themselves in a fun-house mirror. The reflection is hilarious but not really you. The nose is yours but swollen out of proportion.

Take the issue of getting your own planet, for example. Elder Price talks about a planet for himself and one for Jesus. Those are not really core Mormon beliefs. Mormon scriptures and Church leaders don't say anything about people getting their own planets. The idea is more like lore than doctrine.

Mormons do believe in the principle of theosis, the doctrine that God wants humans to become like himself - in effect gods. That belief leads Mormons to speculate about creation. Will beings with god-like qualities have the powers to form earths? Perhaps, who knows? 
There is no fixed doctrine on the subject. Mormons themselves joke about the planet business. But they do take seriously that we may grow up to be like Our Father in Heaven (Kernis, 2011, n.p.).

It was my experience, as Bushman points out, that Mormons do joke among themselves about creating their own planets and worlds. Mormon theology posits that worthy members of the Church may, with adherence to all the tenets and rituals of the faith, become like God, in essence, Gods. It is implied in Mormon theology (distinct from official Church doctrine and/or policy) that if God has created "worlds without number", 6 that as Gods, worthy Mormons might very well do the same. As Bushman observes, however, this is more lore than doctrine, while the specifics of godhood itself are largely undefined and remain effectively mysterious in Mormon theology. 7 In an official statement entitled Becoming like God the Church asserts:

[Certain] limitations make it easy for images of salvation to become cartoonish when represented in popular culture. For example, scriptural expressions of the deep peace and overwhelming joy of salvation are often reproduced in the well-known image of humans sitting on their own clouds and playing harps after death. Latter-day Saints' doctrine of exaltation is often similarly reduced in media to

6 "And worlds without number have I created; and I also created them for mine own purpose; and by the Son I created them, which is mine Only Begotten" (Moses 1:33, Pearl of Great Price).

7 Mormon temple rituals provide members of the Church with certain assurances and promises with regard to the potential of godhood in the life to come. However, further discussion of these rituals are beyond the scope of this paper. For more information see Buerger's (1987), The development of the Mormon temple endowment ceremony, and also Buerger's (1994), The mysteries of godliness: A history of Mormon temple worship. 
a cartoonish image of people receiving their own planets... while few Latter-day Saints would identify with caricatures of having their own planet, most would agree that the awe inspired by creation hints at our creative potential in the eternities (The Church of Jesus Christ of LatterDay Saints, 2014a, n.p.).

In response to the above statement from the Church, Wiener-Bronner (2014), in Mormons don't technically get a planet once they die, say Mormons, opines: "So Mormons don't believe in heaven as planet per se, but they also don't not believe in it" (n.p.). From the perspective of my personal experience in the Church, I would have to agree that while the doctrine of the Church leaves some room for interpretation in terms of what the afterlife might look like, Mormon conceptualisations of exaltation do tend to include the creation of worlds.

The fifth president of the Church, President Lorenzo Snow made a statement about God that is well-known among Mormons. He said: "As man now is, God once was; as God now is, man may be" (Huggins, 2006, p. 549). Mormon theology insists that God is a personage of glorified flesh and bone and that, unlike orthodox Christianity, Jesus is believed to be a separate being from God, not the human incarnation of God. Paulsen (1995) refers to this aspect of Mormon theology as "divine embodiment" and argues: "The doctrine that God the Father and God the Son are embodied persons, humanlike in form, has rich implications for both philosophical anthropology and theology, and it is one of the most distinctive teachings of the Restoration" (p. 7). As missionaries we taught investigators that if they joined the Church and followed the precepts of the restored gospel, and received for themselves and their families, the sacred instructions of the temple, that they had the potential to become like God, or in other words, to become Gods. The logic being that a truly loving Father in Heaven would want his children to be like him. 
Continuing with the interview, Kernis (2011) asks Bushman the following:

Here's another lyric: "I believe that God lives on a planet called Kolob. / I believe that Jesus has his own planet as well. And I believe that the Garden of Eden was in Jackson County, Missouri." All based in Mormon doctrine? (n.p.)

To which Bushman replies:

Does God live on a planet called Kolob? Again, pretty close, but not precisely accurate. The astronomical reflections of Abraham in one Mormon scripture do speak of God dwelling close to a planet named Kolob. The place of God's dwelling registers only as a tiny detail in Mormon thinking, but the idea that He does have a dwelling place is of immense importance.

Mormon theology differs radically from conventional Christianity in locating God in time and space. He is not outside creation as traditionally believed. He is part of the physical universe, a being like the God in Michelangelo's Sistine Chapel who could touch Adam's finger with his own if He chose (Kernis, 2011, n.p.).

The Mormon scripture to which Bushman refers come from the Book of Abraham:

3 And the Lord said unto me: These are the governing ones; and the name of the great one is Kolob, because it is near unto me, for I am the Lord thy God: I have set this one to govern all 
those which belong to the same order as that upon which thou standest.

4 And the Lord said unto me, by the Urim and Thummim, that Kolob was after the manner of the Lord, according to its times and seasons in the revolutions thereof; that one revolution was a day unto the Lord, after his manner of reckoning, it being one thousand years according to the time appointed unto that whereon thou standest. This is the reckoning of the Lord's time, according to the reckoning of Kolob.

9 And thus there shall be the reckoning of the time of one planet above another, until thou come nigh unto Kolob, which Kolob is after the reckoning of the Lord's time; which Kolob is set nigh unto the throne of God, to govern all those planets which belong to the same order as that upon which thou standest (Abraham 3:3-4, 9, Pearl of Great Price).

I was fascinated with the Book of Abraham and its origins. A group of Mormons had purchased four mummies and "two or more rolls of papyrus" from entrepreneur, Michael Chandler (Smith, 1835, p. 596). When Joseph Smith began to examine the papyri and translate the hieroglyphics, he said: "...much to our joy [we] found that one of the rolls contained the writings of Abraham" (Smith, 1835, p. 586). I particularly enjoyed looking at and reading about the facsimile below. I was quite captivated and equally mystified by it. 
Image 2: A facsimile from the Book of Abraham, No. 2, Pearl of Great Price

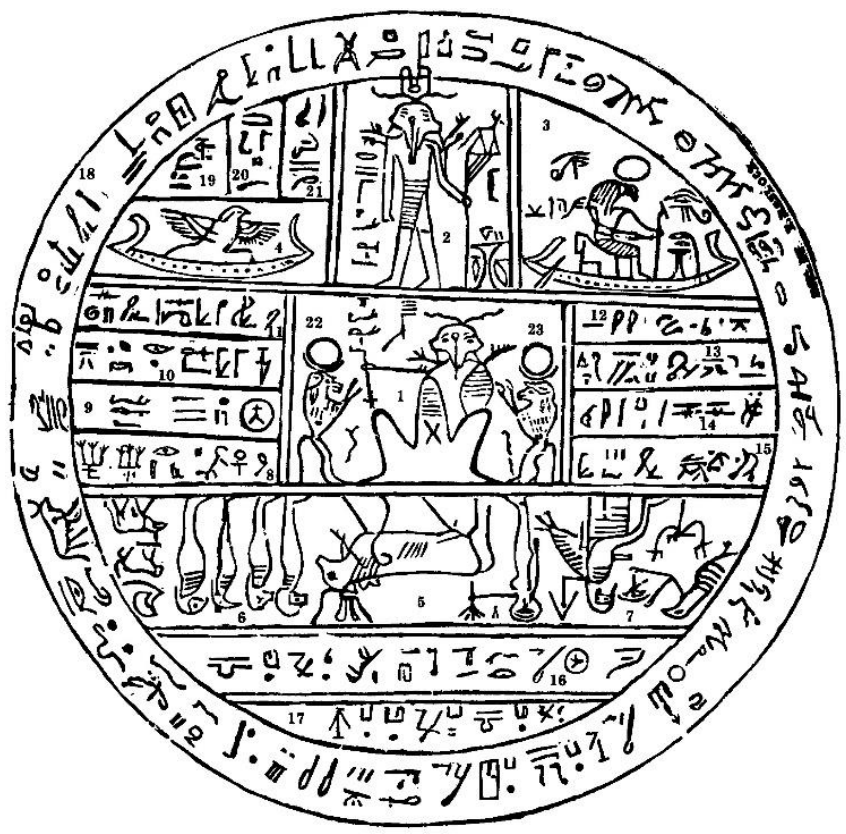

The following are the translations or explanations, by Joseph Smith, found in the Book of Abraham, following the facsimile, which refer specifically to Kolob:

Fig. 1. Kolob, signifying the first creation, nearest to the celestial, or the residence of God. First in government, the last pertaining to the measurement of time. The measurement according to celestial time, which celestial time signifies one day to a cubit. One day in Kolob is equal to a thousand years according to the 
measurement of this earth, which is called by the Egyptians Jah-oh-eh.

Fig. 2. Stands next to Kolob, called by the Egyptians Oliblish, which is the next grand governing creation near to the celestial or the place where God resides; holding the key of power also, pertaining to other planets; as revealed from God to Abraham, as he offered sacrifice upon an altar, which he had built unto the Lord.

Fig. 4. Answers to the Hebrew word Raukeeyang, signifying expanse, or the firmament of the heavens; also a numerical figure, in Egyptian signifying one thousand; answering to the measuring of the time of Oliblish, which is equal with Kolob in its revolution and in its measuring of time.

Fig. 5. Is called in Egyptian Enish-go-ondosh; this is one of the governing planets also, and is said by the Egyptians to be the Sun, and to borrow its light from Kolob through the medium of Kae-e-vanrash, which is the grand Key, or, in other words, the governing power, which governs fifteen other fixed planets or stars, as also Floeese or the Moon, the Earth and the Sun in their annual revolutions. This planet receives its power through the medium of Kli-flos-is-es, or Hah-ko-kau-beam, the stars represented by numbers 22 and 23, receiving light from the revolutions of Kolob.

Kolob seems to have captured the imaginations of Mormons (and non-Mormons as is the case with The Book of Mormon 
musical) despite being mentioned only a few times in the Book of Abraham. Kolob is the subject matter of one of my favourite pieces of Mormon music, Hymn 284 in Hymns of The Church of Jesus Christ of Latter-Day Saints, which draws inspiration from Abraham 3:1-4, 9 and Moses 1:3-4, 33-39 and asks:

If you could hie to Kolob

In the twinkling of an eye,

And then continue onward

With that same speed to fly,

Do you think that you could ever,

Through all eternity,

Find out the generation

Where Gods began to be? (The Church of Jesus Christ of Latter-Day Saints, 1985a, n.p.) 8

Described as the father of Mormon apologetics, Hugh Nibley (1968) recalls, with regard to Egyptian papyri once owned by Joseph Smith, given to the Church as a gift from the Metropolitan Museum of Art in 1967, that “...the Egyptologists who were asked to express their opinions of the Prophet's teachings could only snort and sputter with disgust" (p. 171). While professional Egyptologists have refuted Joseph Smith's work as "utterly absurd" (Nibley, 1968, p. 172), it is important to note that "Joseph Smith never pretended to understand Egyptian, nor that the Book of Abraham was a work of his scholarship" (Nibley, 1968, p. 176). In the 2012 BBC documentary, The Mormon Candidate, John Sweeney interviewed Mormon Apostle, Elder Jeffrey R. Holland. During the interview, Sweeney enquired about the translation of the Book of Abraham:

8 Text: William W. Phelps. Music: English melody, arranged by Ralph Vaughan Williams, from the English Hymnal. 
Sweeney: Joseph Smith got these papyri and he translated them and subsequently as the Egyptologists cracked the code, something completely different came out...

Holland: [Interrupts] All I'm saying... all I'm saying is that what got translated got translated into the word of God. The vehicle for that, I do not understand and don't claim to know and know no Egyptian (Jones, Collyns \& Hetherington, 2012, n.p.). 9

Consistently, the official Church position on the matter is declared thusly:

The veracity and value of the book of Abraham cannot be settled by scholarly debate concerning the book's translation and historicity. The book's status as scripture lies in the eternal truths it teaches and the powerful spirit it conveys. The book of Abraham imparts profound truths about the nature of God, His relationship to us as His children, and the purpose of this mortal life. The truth of the book of Abraham is ultimately found through careful study of its teachings, sincere prayer, and the confirmation of the Spirit. (The Church of Jesus Christ of Latter-Day Saints, 2014b, n.p.).

With regard to the location of the Garden of Eden being in Jackson County, Missouri, Van Orden (1994), published on the official Church website claims that "[y]et relative to the locale of the site of the Garden of Eden, the prophet Joseph Smith learned

9 I personally transcribed these words from the documentary. 
through revelation that Jackson County was the location of a Zion to be and the New Jerusalem to come" (n.p.). Furthermore:

The Prophet first visited Jackson County, Missouri, in the summer of 1831. The Prophet visited Jackson County again in April and May 1832. On one of the occasions, or perhaps both, the Prophet Joseph apparently instructed his close associates, and perhaps even a general Church gathering, that the ancient Garden of Eden was also located in Jackson County (Van Orden, 1994, n.p.).

In a revelation given to Joseph Smith in Doctrine and Covenants $57: 1-3$ it states:

1 Hearken, O ye elders of my church, saith the Lord your God, who have assembled yourselves together, according to my commandments, in this land, which is the land of Missouri, which is the land which I have appointed and consecrated for the gathering of the saints.

2 Wherefore, this is the land of promise, and the place for the city of Zion.

3 And thus saith the Lord your God, if you will receive wisdom here is wisdom. Behold, the place which is now called Independence is the center place; and a spot for the temple is lying westward, upon a lot which is not far from the courthouse.

In a further interview question Kernis (2011) asks Bushman: 
One more: "And I believe that in 1978, God changed his mind about black people!" After years of excluding African-Americans, church president and Living Prophet Spencer W. Kimball did announce that he had received a revelation from God about opening the doors wider, right? (n.p.).

To which Bushman answers:

Some things in the lyrics are pretty close to the truth. For over a century, the Church did deny the priesthood to blacks for reasons Mormons themselves did not understand: perhaps there was a doctrinal basis, perhaps it was a policy adopted by Brigham Young in an era when blacks were commonly excluded from many white activities.

In 1978 Church president Spencer Kimball extended the priesthood to all worthy males, much to the relief of the Church membership. It was not a matter of God changing His mind, as they lyrics say; the Church always believed blacks would receive the priesthood some day. It was only a question of when. The Church is conservative in the classic sense of changing slowly, but it does change deliberately in its own good time (n.p.).

Early in my Mormon experience, I familiarised myself with the writing of deceased Church Apostle, Elder Bruce R. McConkie. His highly controversial book, Mormon doctrine (McConkie, 1966), intrigued me greatly. The tone of the book was authoritative and abrupt. Within its encyclopaedic pages, 
he openly identified the Roman Catholic Church as the church of the devil. Interestingly, his comments did not deter me from my fascination with Catholicism that I had developed well before I encountered Mormonism, as my Irish lineage ensured that Catholicism was part of my whakapapa. I was interested too in the Mormon policy that denied the full blessings of the Church, including priesthood (the Mormon Church has a lay priesthood which all "worthy" men may be ordained into) to those of African descent from the mid-1800s up until 1978 (The Church of Jesus Christ of Latter-Day Saints, 2018). With regard to people of African descent, McConkie (1966) claimed:

Of the two-thirds who followed Christ, however, some were more valiant than others ....Those who were less valiant in pre-existence and who thereby had certain spiritual restrictions imposed upon them during mortality are known to us as the negroes. Such spirits are sent to earth through the lineage of Cain, the mark put upon him for his rebellion against God and his murder of Abel being a black skin. Noah's son Ham married Egyptus, a descendant of Cain, thus preserving the negro lineage through the flood. Negroes in this life are denied the priesthood; under no circumstances can they hold this delegation of authority from the Almighty. The gospel message of salvation is not carried affirmatively to them, although sometimes negroes search out the truth, join the Church, and become by righteous living heirs of the celestial kingdom of heaven. President Brigham Young and others have taught that in the future eternity worthy and qualified negroes will receive the priesthood and every gospel blessing available to any man. The present status of the negro rests purely and 
simply on the foundation of pre-existence. Along with all races and peoples he is receiving here what he merits as a result of the long pre-mortal probation in the presence of the Lord ...The negroes are not equal with other races where the receipt of certain spiritual blessings are concerned, particularly the priesthood and the temple blessings that flow therefrom, but this inequality is not of man's origin. It is the Lord's doing (pp. 526-527).

McConkie's (1966) Mormon doctrine was never considered to be official Church doctrine, however, the ideas were absorbed uncritically, in my view, by some of the membership. In my experience speaking with Mormons during my time as a member of the Church, I found that many Mormons believed in the theories around race and priesthood, many citing the fact that from a Mormon perspective, access to the priesthood extended from Jews, to Gentiles and eventually to everyone else, including black people, and that this was part of a divine plan. In saying that, the Church has officially renounced any and all theories with regard to race and priesthood in an official Church statement, originally published in December 2013, entitled Race and the priesthood:

Today, the Church disavows the theories advanced in the past that black skin is a sign of divine disfavor or curse, or that it reflects unrighteous actions in a premortal life; that mixed-race marriages are a $\underline{\sin }$; or that blacks or people of any other race or ethnicity are inferior in any way to anyone else. Church leaders today unequivocally condemn all racism, past and present, in any form (The Church of Jesus Christ of Latter-Day Saints, 2018a, n.p.). 


\section{Conclusion}

This article has explored some of my thoughts and reflections about The Book of Mormon musical. I was member of the Church of Jesus Christ of Latter-Day Saints from 1996 through to 2003. In the six years that I was involved with the Mormon Church I had many wonderful and varied experiences. While serving a Mormon mission was at times harrowing - requiring frequent use of the "turn it off" strategy! - it was a time of great growth and change. Being excommunicated from the Church in 2003 was an extremely difficult time in my life. The Book of Mormon provided a rather warped and distorted refresher course in the tenets of Mormonism. It reminded me of some of the doctrine of Mormonism that I had to teach as a missionary and it caused me to reflect further on my own developing theology and faith. 


\section{References}

Argetsinger, G. S. (2016). The Book of Mormon musical and the Cumorah experience. In M. E. Shaw \& H. Welker (Eds), Singing and dancing to The Book of Mormon: Critical essays on the Broadway musical (pp. 17-28). Lanham, MD: Rowman \& Littlefield.

Ashworth, J. (2016). Faith in fiction: Creative practice and the persistence of doubt. In M. E. Shaw \& H. Welker (Eds), Singing and dancing to The Book of Mormon: Critical essays on the Broadway musical (pp. 61-75). Lanham, MD: Rowman \& Littlefield.

Brooks, D. (2011, April 21). Creed or chaos. The New York Times. Retrieved from: https://www.nytimes.com/2011/04/22/opinion/22brooks.html? $\mathrm{r}=1$

Buerger, D. J. (1987). The development of the Mormon temple endowment ceremony. Dialogue: A Journal of Mormon Thought, 20(4), 33-76.

Buerger, D. J. (1994). The mysteries of godliness: A history of Mormon temple worship. San Francisco, CA: Smith Research Associates.

The Church of Jesus Christ of Latter-Day Saints (1985a). Hymns of the Church of Jesus Christ of Latter-Day Saints. Salt Lake City, UT: Author.

The Church of Jesus Christ of Latter-Day Saints (1985b). A parent's guide. Salt Lake City, UT: Author. Retrieved from: https://www.lds.org/manual/a-parents-guide/chapter5 ?lang=eng

The Church of Jesus Christ of Latter-Day Saints (1986). Uniform system for teaching the gospel. Salt Lake City, UT: Author.

The Church of Jesus Christ of Latter-Day Saints (2006). Missionary handbook. Salt Lake City, UT: Author. Retrieved from: https://www.lds.org/bc/content/ldsorg/topics/missionary/Missi onaryHandbook2006Navigate.pdf

The Church of Jesus Christ of Latter-Day Saints (2014a). Becoming like God. Retrieved from: https://www.lds.org/topics/becoming-likegod?lang=eng

The Church of Jesus Christ of Latter-Day Saints (2014b). Translation and historicity of the Book of Abraham. Retrieved from: https://www.lds.org/topics/translation-and-historicity-of-thebook-of-abraham?lang=eng

The Church of Jesus Christ of Latter-Day Saints (2018a). Race and the priesthood. Retrieved from: https://www.lds.org/topics/race-andthe-priesthood?lang=eng

The Church of Jesus Christ of Latter-Day Saints (2018b). Same-sex attraction. Retrieved from: https://www.lds.org/topics/same-sexattraction?lang=eng

Cima, G. A. (2016). The Book of Mormon's African fantasies. In M. E. Shaw \& H. Welker (Eds), Singing and dancing to The Book of Mormon: Critical essays on the Broadway musical (pp. 129-142). Lanham, MD: Rowman \& Littlefield. 
Cragun, R. T. (2016). "A Mormon just believes." And so do lots of other people. In M. E. Shaw \& H. Welker (Eds), Singing and dancing to The Book of Mormon: Critical essays on the Broadway musical (pp. 29-39). Lanham, MD: Rowman \& Littlefield.

DeLashmutt, M. W. \& Hancock, B. (2008). Prophetic profanity: South Park on religion or thinking theologically with Eric Cartman. In J. A. Weinstock (Ed.), Taking South Park seriously (173-191). Albany, NY: SUNY Press.

Farmer, J. (2011). Why The Book of Mormon (the musical) is awesomely lame. Religious Dispatches. Retrieved from: www.religiondispatches.org/archives/culture/4743/why; Hal Boyd, "LDS Scholar Richard Lyman Bushman Talks 'Mormon' Musical," Deseret News, Aug. 28, 2011, https://www. deseretnews.com/article/700147768/LDS-scholar-Richard-

Lyman-Bushmantalks-Mormon-musical.html

Graham, P. K. (2007). We shall make music: Stories of the Primary songs and how they came to be. Springville, UT: Horizon.

Hetrick, A. \& Blank, M. (2011). Theatre by design: The Book of Mormon's designers Scott Pask and Ann Roth. Retrieved from: http:/ / www.playbill.com/article/theatre-by-design-the-book-ofmormons-designers-scott-pask-and-ann-roth-com-179852

Hicks, M. (2011). Elder Price Superstar. Dialogue: A Journal of Mormon Thought, 44(4), 226-236.

Hoxworth, K. (2017). Strains of the Enlightenment: Making belief in American secularism and African difference in The Book of Mormon. Modern Drama, 60(3), 364-386.

Huggins, R. V. (2006). Lorenzo Snow's couplet: "As man now is, God once was; as God now is, man may be": "No functioning place in present-day Mormon doctrine?" A response to Richard Mouw. Journal of the Evangelical Theological Society, 49(3), 549-568.

Jones, J. (Producer), Collyns, S. \& Hetherington, L. (Executive Producers). (2012). The Mormon Candidate [motion picture]. United Kingdom: BBC.

Joseph, R. A. (2012). Intercultural exchange, Matakite Maori and the Mormon Church. In H. Morrison, L. Paterson, B. Knowles \& M. Rae, Mana Maori and Christianity (pp. 43-72). Wellington, New Zealand: Huia.

Kernis, J. (2011, June 27). Richard Bushman: 'The Book of Mormon' is like looking into a fun-house mirror; the reflection is hilarious but not really you [Blog post]. CNN. Retrieved from: https://web.archive.org/web/20111206132857/http://inthearen a.blogs.cnn.com/2011/06/27/richard-bushman-the-book-ofmormon-is-like-looking-into-a-fun-house-mirror-the-reflection-ishilarious-but-not-really-you/

Lim, S. (2016). Good intentions and (un)acceptable laughter: How the carnival inverts cross-cultural relationships in The Book of Mormon. In M. E. Shaw \& H. Welker (Eds), Singing and dancing to The Book of Mormon: Critical essays on the Broadway musical (pp. 3-15). Lanham, MD: Rowman \& Littlefield. 
McConkie, B. (1966). Mormon doctrine. Salt Lake City, UT: Deseret Book Company.

Newhouse, W. (2016). Believing part-way: Book of Mormon and postsecular America. In M. E. Shaw \& H. Welker (Eds), Singing and dancing to The Book of Mormon: Critical essays on the Broadway musical (pp. 79-91). Lanham, MD: Rowman \& Littlefield.

Nibley, H. (1968). Prolegomena to any study of the Book of Abraham. Brigham Young University Studies, 8(2), 171-178.

O'Connell, S. (2016). From "Sal Tlay Ka Siti" to "I am Africa": Parody, politics, and musical representations of cultural and national identity in The Book of Mormon. In M. E. Shaw \& H. Welker (Eds), Singing and dancing to The Book of Mormon: Critical essays on the Broadway musical (pp. 113-127). Lanham, MD: Rowman \& Littlefield.

Parker, T., Lopez, R. \& Stone, M. (2011). The Book of Mormon. New York, NY: Harper Collins.

Parker, T., Lopez, R. \& Stone, M. (2012). The Book of Mormon: The testament of a Broadway musical. New York, NY: Harper Collins.

Patton, M. S. (1986). Twentieth-century attitudes toward masturbation. Journal of Religion and Health, 25(4), 291-302.

Paulsen, D. L. (1995). The doctrine of divine embodiment: Restoration, Judeo-Christian, and philosophical perspectives. BYU Studies Quarterly, 35(4).

Peterson, M. E. (1995). Keep your hands to yourself: Excerpts from Steps in overcoming masturbation: A guide to self-control [Pamphlet]. Salt Lake City, UT: The Church of Jesus Christ of Latter-Day Saints.

Shaw, M. E. (2016). Negative capability in The Book of Mormon musical. In M. E. Shaw \& H. Welker (Eds), Singing and dancing to The Book of Mormon: Critical essays on the Broadway musical (pp. 93-109). Lanham, MD: Rowman \& Littlefield.

Sheppard, C. (2013). The Book of Mormon [Review of the book The Book of Mormon by T. Parker, R. Lopez \& M. Stone]. Religious Studies Review, 39(2), 98.

Sirvent, R. \& Baker, N. (2016). Reinhold Niebuhr and religious foolishness: "A Mormon just believes". In M. E. Shaw \& H. Welker (Eds), Singing and dancing to The Book of Mormon: Critical essays on the Broadway musical (pp. 43-59). Lanham, MD: Rowman \& Littlefield.

Smith, J. S. (1835). History, 1838-1856, volume B-1 [1 September 18342 November 1838]. Retrieved from: http://www.josephsmithpapers.org/paper-summary/history1838-1856-volume-b-1-1-september-1834-2-november-1838/50

Van Orden, B. A. (1994). What do we know about the location of the Garden of Eden? Retrieved https://www.lds.org/ensign/1994/01/i-have-a-question/whatdo-we-know-about-the-location-of-the-garden-of-eden?lang=eng

Welker, H. (2016). The Book of Nabulungi: Stand next to him and watch (or, mostly him). In M. E. Shaw \& H. Welker (Eds), Singing and 
dancing to The Book of Mormon: Critical essays on the Broadway musical (pp. 143-158). Lanham, MD: Rowman \& Littlefield.

White, B. H. (2010). A historical analysis of how Preach My Gospel came to be. Unpublished master's thesis, Brigham Young University, Provo, UT. 